\title{
DÜBLIN
}

Technological University Dublin ARROW@TU Dublin

\section{UCC/BDCAT tutorial chairs' welcome}

\author{
Yan Tang \\ Hohai University, Nanjing \\ Tamara Matthews \\ Technological University Dublin, tamara.matthews@tudublin.ie
}

Follow this and additional works at: https://arrow.tudublin.ie/scschcomoth

Part of the Computer Sciences Commons

\section{Recommended Citation}

Tang, Yan and Matthews, Tamara, "UCC/BDCAT tutorial chairs' welcome" (2019). Other resources. 20. https://arrow.tudublin.ie/scschcomoth/20

This Other is brought to you for free and open access by the School of Computer Sciences at ARROW@TU Dublin. It has been accepted for inclusion in Other resources by an authorized administrator of ARROW@TU Dublin. For more information, please contact arrow.admin@tudublin.ie, aisling.coyne@tudublin.ie, gerard.connolly@tudublin.ie.

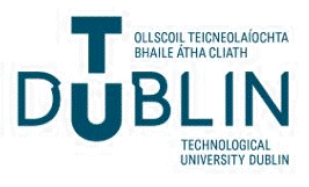




\section{UCC/BDCAT Tutorial Chairs' Welcome}

The call for tutorials at UCC'19 and BDCAT'19 attracted submissions from Australia and Europe. The tutorial chairs reviewed and accepted two revised tutorials, and decided to award a third spot on a FCFS basis to ensure that conference attendees have access to learning resources across all conference topics.

We are pleased to announce that the following tutorials will be offered:

- Good Bye Vendor Lock-in: Getting your Cloud Applications Multi-Cloud Ready!, Marta Różańska (7Bulls.com, Poland) and Kyriakos Kritikos (FORTH-ICS, Greece)

- The Vision of Semantic Web, Molood Barati (Auckland University of Technology, New Zealand)

- Serverless computing and cloud function-based applications, Josef Spillner (Zurich University of Applied Sciences, Switzerland)

We are also pleased to state that following the tradition in UCC and BDCAT, all tutorial instructors agreed to place tutorial summaries as auxiliary content in the proceedings so that you can gain knowledge about the reported fields even when not being able to attend all tutorial sessions.

\author{
Yan Tang \\ UCC'19/BDCAT'19 Tutorial Chair \\ Hohai University, China
}

\author{
Tamara Matthews \\ UCC'19/BDCAT'19 Tutorial Chair \\ Technical University Dublin, Ireland
}

